\title{
Carybdea branchi, sp. nov., a new box jellyfish (Cnidaria: Cubozoa) from South Africa
}

\author{
Lisa-Ann Gershwin' \& Mark J. Gibbons² \\ ${ }^{1}$ Queen Victoria Museum and Art Gallery, Launceston, Tasmania 725o, Australia. E-mail: \\ lisa.gershwin@qvmag.tas.gov.au ${ }^{2} Z$ Zoology Department, University of the Western Cape, Private \\ Bag X'7, Bellville 7535, RSA.E-mail: mgibbons@uwc.acza
}

\begin{abstract}
A common and conspicuous member of the medusan fauna of South Africa has been the subject of repeated taxonomic confusion. After having been mistakenly identified by earlier workers as either Carybdea alata or Tamoy a haplonema, this large and colourful carybdeid is described herein as Carybdea branchi, sp. nov. It is distinguished from its congeners on numerous characters: body to about $8 \mathrm{~cm}$ in life, densely scattered with nematocyst warts over the whole body and abaxial keels of the pedalia; a bulge or lateral thorn on the pedalial canal bend; with 2 dendritic velarial canals per octant, highly diverticulated; with a long manubrium; with greatly bushy epaulette-like phacellae, comprising 20 or more roots tightly clustered; with well developed mesenteries; and with conspicuous brownish pigmented areas over the proximal and distal regions of the pedalia and over the phacellae. A comparative table of the primary diagnostic characters of species in the genus Carybdea is given.
\end{abstract}

Keywords Carybdeida, Carybdeidae, medusae, taxonomy, Cape Town, new species, marine stinger

\section{Introduction}

Very few references exist on the carybdeids in African waters. Species occurring there have typically been attributed to well known species from elsewhere, rather than being recognised for their unique morphology. Haeckel (1880), Uchida (1970), and Branch et al. (1994) reported "Carybdea alata" (= Alatina alata (Reynaud, 1830), see Gershwin 2005b) off South Africa, while Stiasny (1939) reported it off West Africa. From Uchida's (1970) description, it seems quite likely that his specimen is referable to the species described below rather than to the true $A$. alata.

Haeckel (1880) described Carybdea murrayana from West Africa. Mayer (1910), Bigelow (1938), and Kramp (1961) considered C. murrayana to be conspecific with $C$. marsupialis. However, recent studies suggest otherwise (Gershwin 2005a).

Ranson (1945) reported Carybdea marsupialis (Linnaeus, 1758) off Algiers, North Africa; it is currently unclear if this report may be referable to $C$. murrayana, or even possibly to the new species described herein; the range limits of these two species are not yet known. 
Tamoya haplonema Muller (1859) was reported in African waters by Stiasny (1934), Ranson (1949), Kramp (1955; 1959), and Pages et al. (1992). That species is common along western Atlantic shores from Argentina to New York, and is immediately identifiable in having vertical phacellae with the cirri in bands along the perradial sides of the bag-like stomach.

A large and colourful species of Carybdea is common along South African shores, but has been hitherto overlooked as being new to science. The purpose of our paper is to describe this new species of box jellyfish, and in doing so, to rectify some of the mistakes that have been made historically relating to the species.

\section{Materials and methods}

The material described herein was collected from the east and south coasts of South Africa. Material was fixed in $5-10 \%$ formalin in seawater. All taxonomic observations and measurements were made on preserved material unless otherwise noted. Measurements were made with Max-Cal digital calipers to the nearest $0.01 \mathrm{~mm}$. Bell height $(\mathrm{BH})$ was measured from the apex of the bell to the velarial turnover. Diagonal bell width (DBW) was measured across diagonal pedalia on a flattened specimen, at the height where the pedalium joins the exumbrella of the bell. Interrhopalial width (IRW) was measured between adjacent rhopalia, with the specimen flattened. Tentacle base width (TBW) was measured at the uppermost part of the tentacle, immediately below the pedalium; if the tentacle was flattened, width was measured across the widest points. In opaque specimens, phacellae were studied by making a small incision in the upper corners of the bell, and then pulling back a small amount of mesoglea to expose the floor of the stomach, or by opening up the full length of the body wall to expose the stomach, and then opening the stomach in the same manner. In transparent specimens, phacellae were obvious. Nematocysts were examined and measured with a Leica DMLB compound microscope and Leica IM-50 Image Manager v. 1.20 for Windows; all observations and photographs were made under 400x magnification. Nematocysts were identified following the keys of Calder (1974), Mariscal (1971), Williamson et al. (1996), and Gershwin (2006).

Abbreviations used. South African Museum, Cape Town (SAMCT); Natural History Museum, London (NHM); Nationaal Natuurhistorisch Museum, Naturalis, Leiden (NNM); South Australian Museum, Adelaide (SAMA); and Zoological Museum, University of Copenhagen (ZMUC). Specimens from the Ronald V. Southcott collection are indicated with his initials (RVS) and correspond to extensive notes archived in the South Australian Museum.

Class Cubozoa Werner, 1973

Order Carybdeida Gegenbaur, 1856 (sensu

Werner, 1984) Family Carybdeidae

Gegenbaur, 1856 Genus Carybdea Peron \&

Lesueur, 1810

Carybdea branchi, sp. nov.

Plates 1-3 
Carybdea alata. - Uchida 1970: 291-293, text fig. 2; off Cape Town. - Branch et al., 1994: 32, pl. 13.1; SW Africa. Tamoya haplonema. - Pages et al., 1992: 57-58, fig. 67. Carybdea n. sp. (Cape Town) Gershwin, 2005: throughout. Carybdea n. sp. B Gershwin, 2006: 9.

Holotype: SAMCT H4863, 18 January 2001, SE corner of Alfred Basin, in front of the Two Oceans Aquarium, V\&A Waterfront, Cape Town [ $\left.33^{\circ} 54.527^{\prime} \mathrm{S}, 018^{\circ} 25.074^{\prime} \mathrm{E}\right]$, coll. by L. Gershwin \& L. Hoensen, hand-dipped from surface; $68.03 \mathrm{~mm} \mathrm{BH}, 95.05 \mathrm{~mm}$ DBW, $48.22 \mathrm{~mm}$ IRW, $6.93 \mathrm{~mm}$ TBW.

Paratypes: SAMA H923 (=RVS A262), Soldhana Bay, South Africa, 28 April 1958; $32.04 \mathrm{~mm} \mathrm{BH}, 44.27 \mathrm{~mm}$ DBW, $21.72 \mathrm{~mm}$ IRW, tentacle width $2.64 \times 1.87 \mathrm{~mm}$. SAMA H924 (=RVS A389F), South Africa, April 1959?; $41.70 \mathrm{~mm} \mathrm{BH,} 50.19 \mathrm{~mm}$ DBW, $24.89 \mathrm{~mm}$ IRW, pedalium $22.03 \mathrm{~mm}$ TL, tentacle width $3.51 \mathrm{~mm}$. SAMA H925 (=RVS A389A), same coll. data as H924; $39.86 \mathrm{~mm} \mathrm{BH,} 43.66 \mathrm{~mm}$ DBW, $21.51 \mathrm{~mm}$ IRW. SAMA H926 (=RVS A389 H, I), same coll. data as H924; 2 specimens: A) 31.00 mm BH, 40.37 mm DBW, 20.76 mm IRW, $3.16 \mathrm{~mm}$ ATBW; B) $38.46 \mathrm{~mm} \mathrm{BH,} \mathrm{50.15} \mathrm{mm} \mathrm{DBW,} 24.06 \mathrm{~mm}$ IRW, $3.21 \mathrm{~mm}$ ATBW. SAMA H927 (=RVS A298), South Africa, Langebaan, coll. by University of Cape Town (Ecol. Survey LB.514), 28 April 1958; $41.98 \mathrm{~mm} \mathrm{BH,} 51.25 \mathrm{~mm}$ DBW, 25.85 mm IRW. SAMA H928 (=RVS A389J), same coll. data as H924; $25.73 \mathrm{~mm} \mathrm{BH,} 29.95 \mathrm{~mm}$ DBW, $11.91 \mathrm{~mm}$ IRW. SAMA H929, same data as H925; $48.00 \mathrm{~mm} \mathrm{BH,} 51.86 \mathrm{~mm}$ DBW, 26.16 mm IRW, largest tentacle $6.32 \times 3.65 \mathrm{~mm}$ diameter. SAMA H930 (=RVS A389M), South Africa, coll. by ?University of Cape Town, April 1959?, immature, $17.61 \mathrm{~mm} \mathrm{BH}, 22.25 \mathrm{~mm}$ DBW, $9.94 \mathrm{~mm}$ IRW. SAMA H931 (=RVS A389L), same coll. data as H930, immature, $22.70 \mathrm{~mm}$ BH, $25.92 \mathrm{~mm}$ DBW, $11.76 \mathrm{~mm}$ IRW. SAMA H932 (=RVS A389K), same coll. data as H930; immature, $20.45 \mathrm{~mm} \mathrm{BH}, 26.00 \mathrm{~mm}$ DBW, $12.86 \mathrm{~mm}$ IRW. SAMA H933 (=RVS A390), University of Cape Town, SB 112, South Africa, 14 July 1946; immature, 16.29 mm BH, 20.33 mm DBW, 11.23 mm IRW. SAMA H934 (=RVS A376), University of Cape Town, South Africa, probably Langebaan, 20 August 1946; 3 specimens: A) $49.02 \mathrm{~mm} \mathrm{BH}$, 62.75 mm DBW, 27.57 mm IRW, 3.08 mm ATBW; B) $43.91 \mathrm{~mm} \mathrm{BH,} 53.54 \mathrm{~mm}$ DBW, 24.95 mm IRW; C) $44.91 \mathrm{~mm} \mathrm{BH}, 54.14 \mathrm{~mm}$ DBW, $24.04 \mathrm{~mm}$ IRW. SAMA H1064, same coll. data as H924; $37.36 \mathrm{~mm} \mathrm{BH,} 46.88 \mathrm{~mm}$ DBW, $21.64 \mathrm{~mm}$ IRW. NNM 5228, Port Elisabeth, 26 May 1936; 4 specimens, 62.17 - 65.90 mm BH. NHM 2000.1800-1803, Simon's Town Docks, False Bay, South Africa, coll. 17 November 1938 by the Discovery Expedition; 4 specimens, BH (mm): 44.50, 46.22, 47.44, 53.34. SAMCT H4860, no loc. data, coll. by G. Branch; $57.60 \mathrm{~mm} \mathrm{BH,} 75.33 \mathrm{~mm}$ DBW, $36.58 \mathrm{~mm}$ IRW. SAMCT 4861, off Langebaan Jetty, 29 September 1959, coll. by University of Cape Town Research, by hand at surface; $37.92 \mathrm{~mm} \mathrm{BH}, 49.82 \mathrm{~mm}$ DBW, $24.58 \mathrm{~mm}$ IRW, $3.94 \mathrm{~mm}$ TBW. SAMCT H4862, no loc. data, 14 April 1963, coll. by University of Cape Town Ecological Survey \#CP 696A; male, $58.31 \mathrm{~mm} \mathrm{BH}, 84.20 \mathrm{~mm}$ DBW, $39.49 \mathrm{~mm}$ IRW, $5.81 \mathrm{~mm}$ TBW. SAMCT H4864, same data as holotype; 2 specimens: A) $51.20 \mathrm{~mm} \mathrm{BH,} 66.52 \mathrm{~mm}$ DBW, $33.17 \mathrm{~mm}$ IRW; B) $47.45 \mathrm{~mm} \mathrm{BH}, 64.56 \mathrm{~mm}$ DBW, $32.68 \mathrm{~mm}$ IRW. SAMCT H4865, same data as holotype; 4 specimens: A) $37.99 \mathrm{~mm} \mathrm{BH}, 45.65 \mathrm{~mm}$ DBW, $23.35 \mathrm{~mm}$ IRW; B) $36.99 \mathrm{~mm}$ BH, $47.89 \mathrm{~mm}$ DBW, $23.85 \mathrm{~mm}$ IRW; C) $41.78 \mathrm{~mm} \mathrm{BH}, 55.62 \mathrm{~mm}$ DBW, $27.54 \mathrm{~mm}$ IRW; D) $44.57 \mathrm{~mm} \mathrm{BH}, 55.11 \mathrm{~mm}$ DBW, $29.24 \mathrm{~mm}$ IRW. SAMCT H4866, same loc. as holotype but collected 17 January 2001, by L. Gershwin \& G. Branch; 6 specimens: A) $52.83 \mathrm{~mm} \mathrm{BH}$, $70.90 \mathrm{~mm}$ DBW, $32.51 \mathrm{~mm}$ IRW; B) $47.75 \mathrm{~mm} \mathrm{BH,} 59.46 \mathrm{~mm}$ DBW, $30.93 \mathrm{~mm}$ IRW; C) 
42.64 mm BH, 54.41 mm DBW, $26.67 \mathrm{~mm}$ IRW; D) $44.79 \mathrm{~mm} \mathrm{BH,} \mathrm{55.09} \mathrm{mm} \mathrm{DBW,} 28.86$ mm IRW; E) $42.24 \mathrm{~mm} \mathrm{BH,} 53.47 \mathrm{~mm}$ DBW, $30.02 \mathrm{~mm}$ IRW; F) $33.26 \mathrm{~mm} \mathrm{BH}, 40.43 \mathrm{~mm}$ DBW, $18.49 \mathrm{~mm}$ IRW, $27.90 \mathrm{~mm}$ rhopalium to apex, $2.89 \mathrm{~mm}$ TBW, $17.85 \mathrm{~mm}$ outer pedalial length. ZMUC unnumb., False Bay, coll. Papenfuss, "Africana"; 48.56mm BH.

Type locality. Albert Basin, Victoria \& Albert Waterfront, Cape Town, South Africa.

Diagnosis. Carybdea with a large, robust, well sculptured body; nematocyst warts densely scattered over whole body and abaxial keels of pedalia, lacking on adaxial keels; adaxial pedalial keels broadly rounded; bend of pedalial canal with a bulge or lateral thorn; velarial canals 2 per octant, dendritic, highly diverticulated; manubrium long; phacellae greatly bushy; mesenteries well developed; brownish pigmented areas conspicuous over proximal and distal regions of pedalia, as well as over phacellae.

Description. Bell to about $68 \mathrm{~mm}$ in height (after several days in formalin), about 80 $\mathrm{mm}$ live (Plate $1 \mathrm{~A}$ ), with thick, rigid mesoglea, especially apically; with numerous oblong to amorphous small unraised or slightly raised nematocyst warts scattered densely over entire exumbrella (Plate 1B). Coronal indentation shallow just below apex (Plate 1A). Interradius thickened throughout bell height, with deep median furrow reaching all the way to pedalium. Adradial furrows strongly pronounced, deeper in lower half of bell (Plate 2A). Perradius smooth, raised, with rhopaliar niche surrounded by deep horseshoe-shaped furrow (Plate 2A).

Sensory niches 4, perradial, heart-shaped (Plate 2B), with 1 shallow covering scale above and 2 nearly imperceptible scales below; located approximately $1 / 6 \mathrm{BH}$ from velarial turnover; lacking "rhopalial horns". Subumbrellar rhopalial windows shallowly convex, with a small concavity marking junction with rhopalial stalk. Eyes 6 per rhopalium, 2 median lensed eyes plus 4 lateral pigmented eye spots. Rhopalial warts lacking. Statolith shape unknown.

Pedalia about $1 / 2$ bell height (Plate $1 \mathrm{~A}, \mathrm{~B}$ ); outer keel densely covered with low nematocyst warts (Plate 2C), flared from body at junction, such that outer edge of pedalial canal is even with outer body wall, with pedalial keel projecting several $\mathrm{mm}$ beyond; inner keel greatly rounded, nearly hemispherical; without tentacular overhang. Pedalial canal strongly quadratic in cross section throughout length, flared slightly at tentacle insertion; outer portion of bend with broadly rounded bulge or lateral-pointing thorn. 

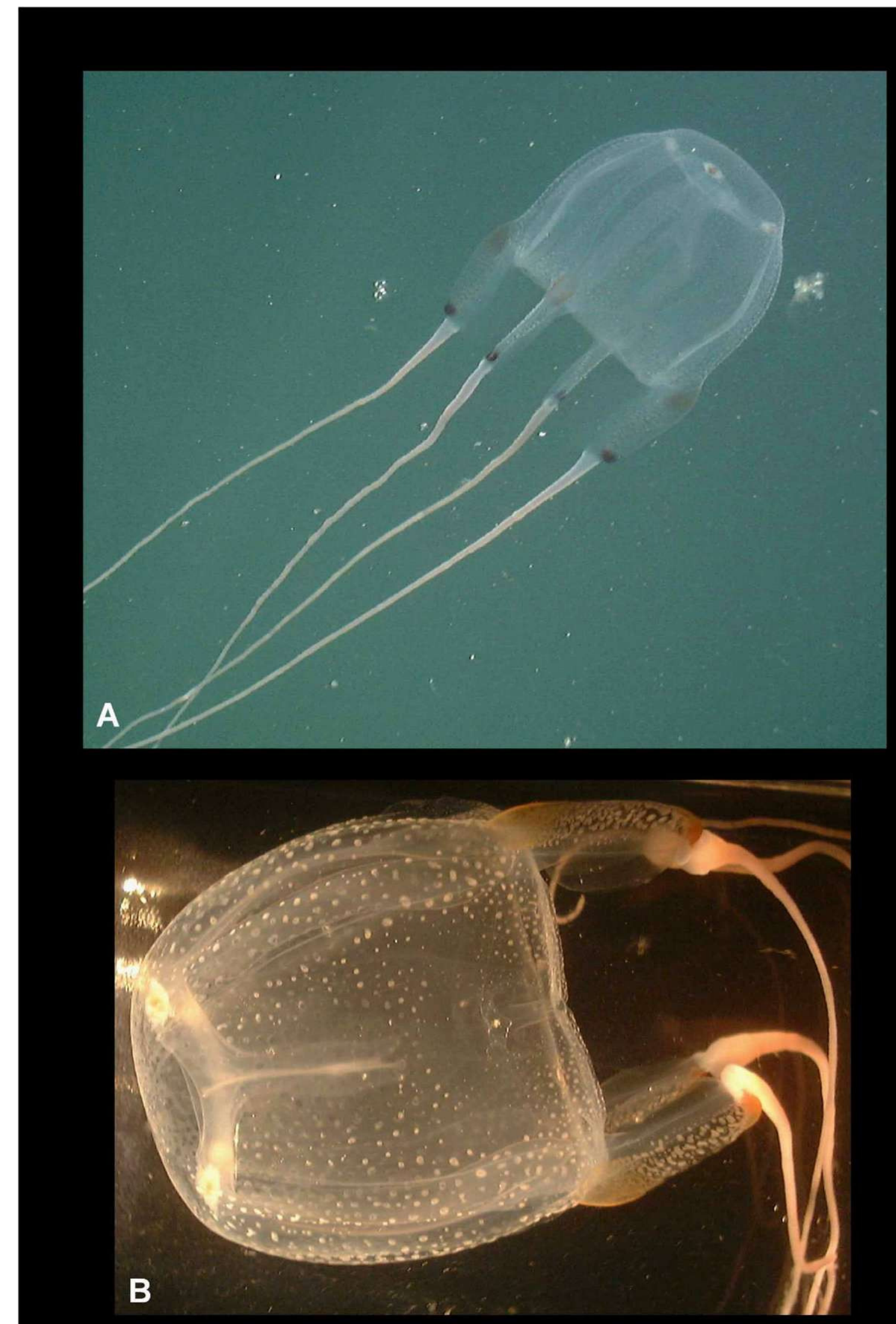

PLATE 1. Carybdea branchi, sp. nov., holotype, live, lateral view. A. In situ. B. In laboratory. Bell height approximately $80 \mathrm{~mm}$ live, $68 \mathrm{~mm}$ preserved in 5-10\% formalin. 


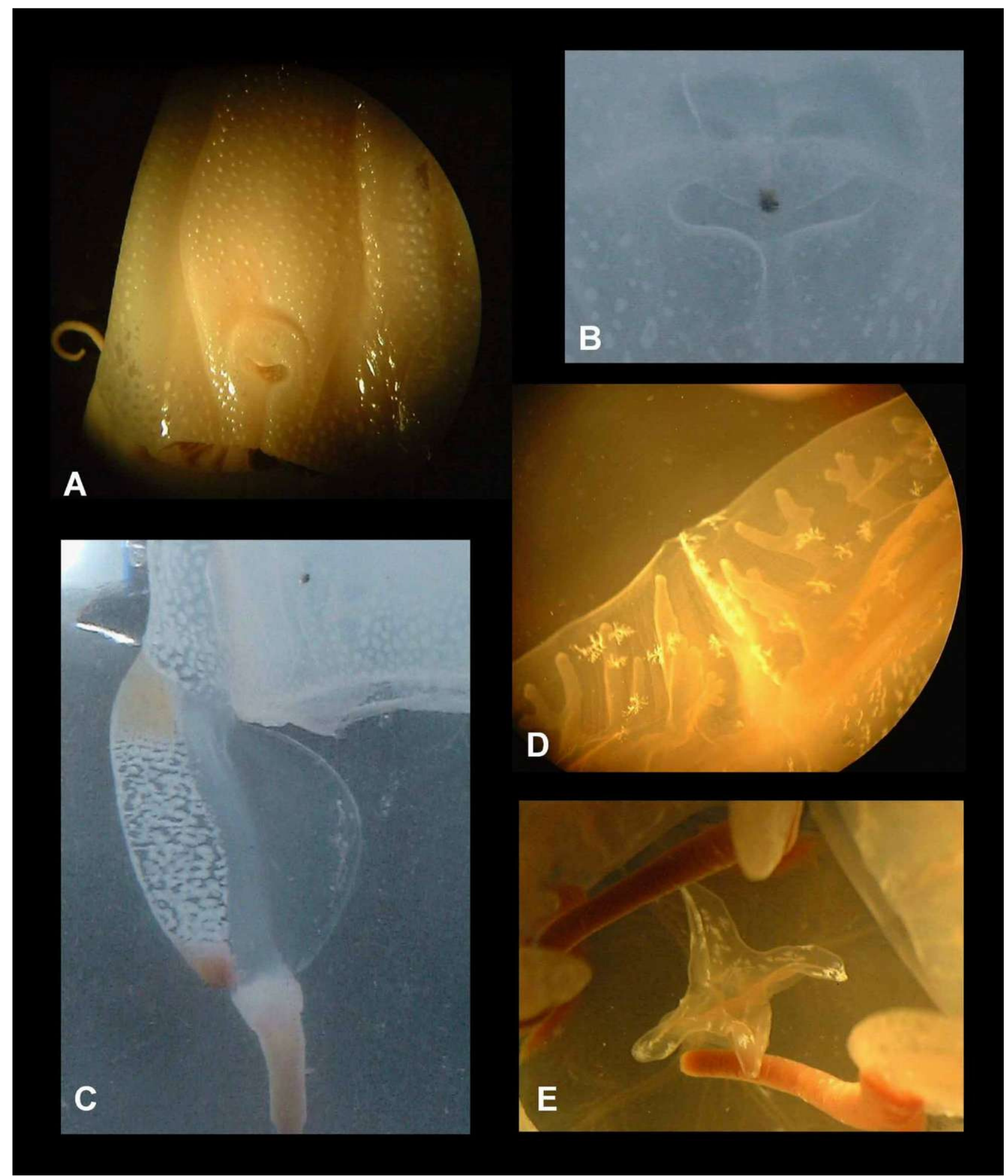

PLATE 2. Carybdea branchi, sp. nov. A. Perradius, note heavy furrows (Paratype SAMA H926). B. Rhopaliar niche ostium, note strongly exaggerated heart-shape (Holotype SAMCT H4863). C. Pedalium, note dense scattering of nematocyst clusters on abaxial keel, absent on adaxial keel (Holotype SAMCT H4863). D. Velarium, note lateral diverticulations on canals in upper right (Paratype SAMA H923). E. Lips, note long, narrow shape (Paratype SAMA 923). Whitish crystals in images D \& E are artifacts of preservative due to age. 
Tentacles 4, with 1 per pedalium; base to about $6 \mathrm{~mm}$ thick, round or flattened somewhat in cross section, gradually tapering distally (Plate 1A); with nematocyst rings all of equal size.

Velarium narrow, lacking nematocyst warts or freckles. Velarial canals 2 per octant, dendritic (Plate 2D), with edges of branches bearing lateral lobations, non-anastomosing. Perradial lappets absent. Frenulum narrowly developed, comprising a single solid gelatinous cord-like strip of tissue, extending only about 3/4 distance to velarial margin.

A

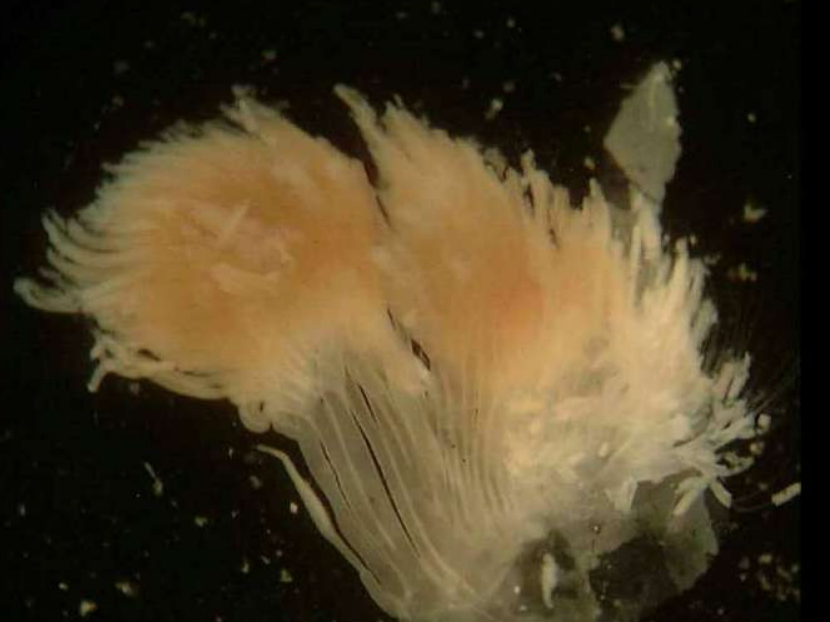

B
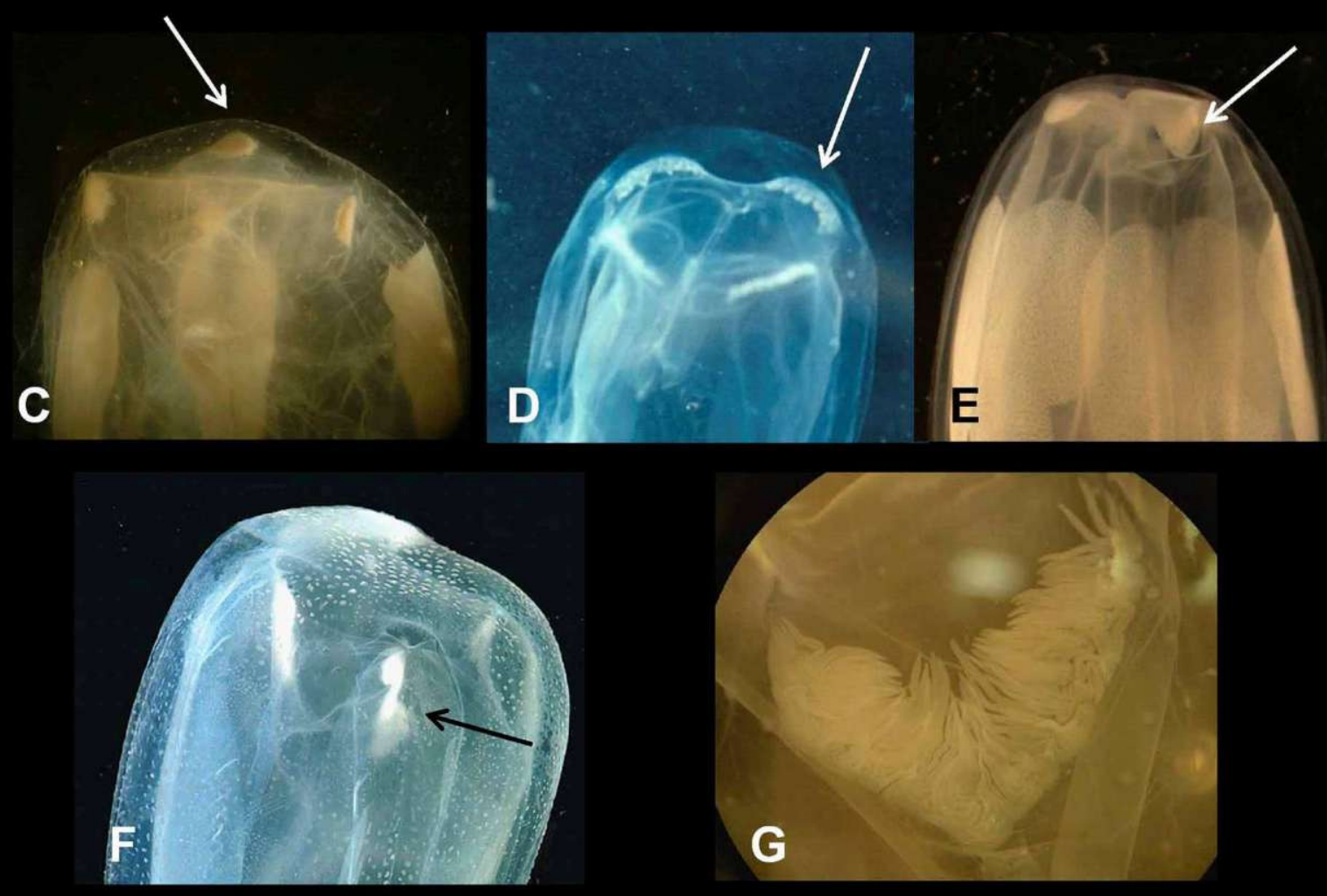
PLATE 3 A. Carybdea branchi, sp. nov., phacella lifted up from stomach (Paratype SAMA A376); note a primary stalk visible at midline, and another behind it. B. Carybdea branchi, sp. nov., phacella dissected out from stomach (Paratype NNM 5228); note numerous primary stalks attached to body as a single bundle. C-F. Carybdeid phacellae forms, indicated with arrows, as viewed without dissection: epaulette-form (C, $C$. marsupialis); linear horizontal (D, C. rastonii, image by I. Bennett); crescentic horizontal (E, Alatina rainensis); linear vertical (F, Tamoya haplonema, image by A. Migotto). G. Crescentic phacella in situ with bell wall peeled away, Alatina mordens.

Stomach flat. Manubrium long, with large, narrowly rounded lips (Plate 2E) reaching to at least halfway down bell cavity in life. Mesenteries flap-like halfway to rhopalium, with cord-like extension to rhopalium. Phacellae (Plate 3A, B) greatly bushy, arising from up to about 20 closely pressed stalks in a single tight bundle; each stalk dendritically branched numerous times to endings of single or paired short, solid cirri. Gonads attached along entire length of interradial septa; narrowly leaf-shaped, typically not overlapping along the interradius in present collection, pleated or simple. Interradial septa lacking perforations.

Colour in life: slightly translucent whitish with conspicuous pigmentation comprising a single dark red blotch on abaxial corner of pedalium at base of each of the 4 tentacles (Plates $1 \mathrm{~A}, \mathrm{~B}, 2 \mathrm{C}$ ), a single small red blotch on apical portion of exumbrella above each of the four phacellae (Plate 1A), and a single faint brownish blotch at "shoulder" of each of the four pedalia (Plates 1A, 2C). Tentacles whitish to faintly pinkish (Plates 1A, 2C).

Nematocysts. As detailed in Gershwin (2005a; 2006: 9, Tab. 1), the tentacular nematocysts are of two types, namely small oval isorhizas (13.39-17.62 pm x 6.06-8.20 pm, $\mathrm{n}=15$ ), and heterotrichous microbasic euryteles (19.33-31.12 pm x 11.98-16.39 pm, $\mathrm{n}=33$ ). There are also two types of bell nematocysts, namely, spherical isorhizas (15.53-20.64 pm, $\mathrm{n}=40$ ), and oval ?amastigophores (15.42-16.30 $\mathrm{pm} \times$ 9.5-1-11.05 pm, $\mathrm{n}=28$ ). The nematocysts of the phacellae and manubrium were not examined.

Etymology. This species is named to honour Professor Emeritus George Branch (University of Cape Town), preeminent zoologist specialising in South African ecosystems.

Distribution. Presently known only from South Africa, from Port Elisabeth along the south coast, to Laangebaan, Soldhana Bay, on the west coast.

Stinging ability. George Branch recounted a sting event that he believed was from this species. The sting occurred around the chest, with a solid band width ca $2.5 \mathrm{~mm}$. The effects were: (1) acute fire-like pain (lasting about 10 minutes), becoming progressively more tolerable as time went on; (2) cessation of heart-beat (for about 15 seconds), followed by abnormally rapid heart beats (guessing about three times the normal rate), followed by cessation of heartbeat once again, and again rapid heartbeats; after three bouts, the heart stabilized.

Whilst sting inhibitors or remedies have not been formally tested on C. branchi, prudence would suggest that this species should be treated similarly to other cubozoans until demonstrated otherwise. As such, the following first aid procedure is recommended:

Call for help if patient is in distress (ring ambulance)

Treat the patient: CPR if necessary

Treat the sting: Douse with vinegar to inhibit further envenomation, then apply ice as needed for pain 
Monitor patient and seek medical attention as necessary

Phylogeny. Gershwin (2005a: figures 3.3, 3.4) found that C. branchi (as Carybdea n.sp. Cape Town) clustered with $C$. rastonii and $C$. mora as the sister group to the Australian form of C. xaymacana in both morphological and partial 18S phylogenies of many species of Cubozoa. This arrangement is surprising, given the closer general resemblance between $C$. xaymacana and $C$. branchi, compared to $C$. rastonii and $C$. branchi (see Table 1). Carybdea mora has long been considered identical to C. rastonii by most authors, but was demonstrated by Gershwin (2006) to have a distinctive cnidome. Carybdea branchi, C. mora, C. marsupialis and C. xaymacana have epaulette-like phacellae, whereas the linear horizontal phacellae in C. rastonii readily separate it from the others. Therefore, discordance exists between the historical morphological interpretation and the molecular and morphological phylogenies in the genus Carybdea. Without doubt, a more thorough phylogenetic analysis of more species and more specimens in the genus will help clarify these questions.

Systematic remarks. Carybdea branchi is distinguished from all other species of Carybdea in having a much larger and more robust body, and lateral digitations on the velarial canals. Of the species currently or recently recognised in the genus, Carybdea branchi is most similar to C. marsupialis, C. mora, C. murrayana, and C. xaymacana based on the shared characters of heart-shaped rhopaliar niches and tightly-clustered, epaulette-like phacellae in each corner of the stomach. However, all five species are easily separated from one another on the number and form of their velarial canals, which are only two per octant and highly dendritic in $C$. branchi and C. mora (the former bearing diverticulations), simpler and numbering 3-4 per octant in C. marsupialis, six per octant in C. murrayana, and only two per octant, but of two types in C. xaymacana. Furthermore, in both $C$. mora and $C$. branchi the bell is evenly scattered with conspicuous nematocyst warts, rather than having them concentrated on the interradii as in other species; however, in $C$. mora the warts are in very small clusters compared to those of $C$. branchi. Carybdea murrayana appears to lack exumbrellar nematocysts. A comparison of primary diagnostic characters is presented in Table 1. 
TABLE 1. Comparison of primary diagnostic characters in the genus Carybdea. Data from original descriptions, examination of type material or new material from type locality where possible, and Gershwin (2005a; 2006b).

\begin{tabular}{|c|c|c|c|c|}
\hline Species & $\begin{array}{l}\text { Bell } \\
\text { height }\end{array}$ & Phacellae & $\begin{array}{l}\text { Rhopaliar } \\
\text { niche }\end{array}$ & $\begin{array}{l}\text { Velarial canals (per } \\
\text { octant) }\end{array}$ \\
\hline $\begin{array}{l}\text { Carybdea } \text { alata } \\
\text { Reynaud, } 1830 \\
=\text { Alatina spp. }\end{array}$ & $230 \mathrm{~mm}$ & $\begin{array}{l}\text { crescentic, with very } \\
\text { long cirri in small } \\
\text { clusters, arranged } \\
\text { parallel }\end{array}$ & T-shaped & $\begin{array}{l}\text { ca. 3, typically simple or } \\
\text { only slightly branched } \\
\text { distally, lacking lateral } \\
\text { lobations }\end{array}$ \\
\hline $\begin{array}{l}\text { Carybdea } \\
\text { sivickisi } \\
\text { Stiasny, } 1926\end{array}$ & $8 \mathrm{~mm}$ & $\begin{array}{l}\text { crescentic, cirri } \\
\text { singly rooted }\end{array}$ & $\begin{array}{l}\text { vertical } \\
\text { keyhole }\end{array}$ & $\begin{array}{l}\text { 2, all paw-like, lacking } \\
\text { lateral lobations }\end{array}$ \\
\hline $\begin{array}{l}\text { Carybdea } \\
\text { rastonii } \\
\text { Haacke, } 1886\end{array}$ & $\begin{array}{l}50-60 \\
\mathrm{~mm}\end{array}$ & $\begin{array}{l}\text { multiple stalked } \\
\text { oblique row, tufted }\end{array}$ & heart-shaped & $\begin{array}{l}\text { 2, all dendritic, lacking } \\
\text { lateral lobations }\end{array}$ \\
\hline $\begin{array}{l}\text { Carybdea } \\
\text { mora } \\
\text { Kishinouye, } \\
1910\end{array}$ & $40 \mathrm{~mm}$ & $\begin{array}{l}\text { multiple-stalked } \\
\text { epaulette, 8-12 main } \\
\text { branches }\end{array}$ & heart-shaped & $\begin{array}{l}\text { 2, all dendritic, lacking } \\
\text { lateral lobations }\end{array}$ \\
\hline $\begin{array}{l}\text { Carybdea } \\
\text { marsupialis } \\
\text { (Linnaeus, } \\
1758 \text { ) }\end{array}$ & $\begin{array}{l}50-60 \\
\mathrm{~mm}\end{array}$ & $\begin{array}{l}\text { multiple-stalked } \\
\text { epaulette, cirri } \\
\text { rooted in pairs }\end{array}$ & heart-shaped & $\begin{array}{l}3-4 \text {, all dendritic, lacking } \\
\text { lateral lobations }\end{array}$ \\
\hline $\begin{array}{l}\text { Carybdea } \\
\text { xaymacana } \\
\text { Conant, } 1897\end{array}$ & $40 \mathrm{~mm}$ & $\begin{array}{l}\text { single-stalked } \\
\text { epaulette of simple } \\
\text { cirri }\end{array}$ & heart-shaped & $\begin{array}{l}2, \text { of two types, } \\
\text { adperradial bifurcated, } \\
\text { adinterradial dendritic, } \\
\text { lacking lateral lobations }\end{array}$ \\
\hline $\begin{array}{l}\text { Carybdea } \\
\text { murrayana } \\
\text { Haeckel, 1880 }\end{array}$ & $60 \mathrm{~mm}$ & $\begin{array}{l}\text { multiple-stalked } \\
\text { epaulette, 10-12 } \\
\text { main branches }\end{array}$ & heart-shaped & $\begin{array}{l}\text { 4-6, all dendritic, lacking } \\
\text { lateral lobations }\end{array}$ \\
\hline $\begin{array}{l}\text { Carybdea } \\
\text { branchi, sp. } \\
\text { nov. }\end{array}$ & $80 \mathrm{~mm}$ & $\begin{array}{l}\text { multiple-stalked } \\
\text { epaulette, about } 20 \\
\text { closely-pressed stalks, } \\
\text { dendritically branched }\end{array}$ & heart-shaped & $\begin{array}{l}\text { 2, all dendritic, with } \\
\text { lateral lobations }\end{array}$ \\
\hline
\end{tabular}


continued.

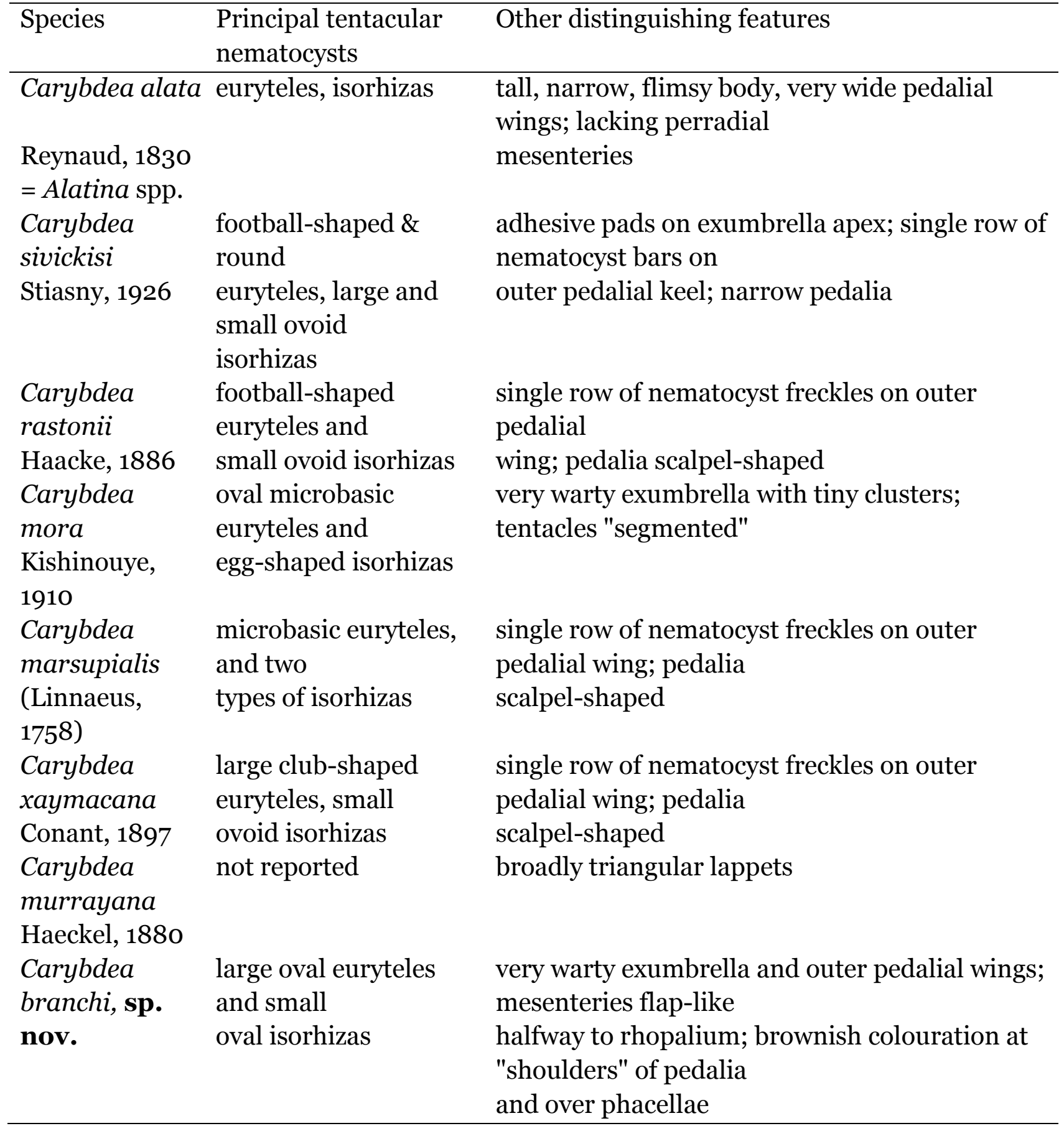

Whilst Uchida (1970) apparently confused C. branchi for Alatina alata (as Carybdea), the former is quite distinctive from the latter. For example, the rhopaliar niche ostia of Alatina are strongly T-shaped (with well developed lateral covering scales), whereas they are typically heart-shaped in C. branchi (Plate 2A; with modestly developed lateral covering scales); even in a case such as that in Plate $2 \mathrm{~B}$, in which the niches of $C$. branchi are somewhat T-shaped, the species would still be immediately distinguished on the basis of the gastric cirri. In Alatina, the cirri are very long and nestled in a parallel fashion in a crescentic row across each interradius (Plate $3 \mathrm{G}$ ), rather than the many-rooted dendritic tuft in C. branchi. From Uchida's (1970: 291-293) description, it seems quite likely that the specimen in question is referable to $C$. branchi rather than to A. alata. 
As mentioned above, C. murrayana from West Africa could be superficially confused with $C$. branchi, because both are relatively large carybdeids from Africa, but the velarial canals quickly separate them: in $C$. branchi the sidewalls of the canals bear many lateral digitations, whereas these are lacking in C. murrayana. Moreover, C. murrayana has many more canals at the velarial turnover (6 per octant, versus 2) but fewer branches after (about 10 tips reaching velarial margin in C. murrayana; but less than 10 reaching margin in $C$. branchi). Mayer (1910), Bigelow (1938), and Kramp (1961) considered C. murrayana to be conspecific with C. marsupialis.

Ranson (1945) and Kramp (1955) reported C. marsupialis off North Africa and Tamoya haplonema off West Africa, respectively; it is currently unclear if these reports may be referable to $C$. murrayana, or even possibly to $C$. branchi. Although the range limits of these two species are not yet known, it seems plausible that the northern hemisphere/tropical reports of C. marsupialis and T. haplonema are not referable to the subtropical/cold temperate southern hemisphere $C$. branchi.

Pages et al. (1992: 57-58) curiously reported a specimen from South Africa identified as Tamoya haplonema. We were unable to examine their figured specimen, but based on the description and illustrations, it seems apparent that they observed C. branchi. The colouration alone is quite distinctive, but perhaps this was overlooked in preservation, which bleaches the colour markings. However, they described the phacellae as being vertical, but they probably failed to appreciate how vertical the phacellae are in the true $T$. haplonema. In T. haplonema, the phacellae root-regions are spread out over a long, vertical region along the sides of the bag-like stomach, in a field maybe five times as high as wide, such that the cirri are not plainly visible through the top of the body (Plate $3 \mathrm{~F}$ ), but must be observed through the side wall or by dissection. In contrast, in $C$. branchi the phacellae root-regions are tightly clustered in small clumps in each corner of the stomach, plainly visible through the top of the bell without dissection. Carybdeid phacellae take numerous forms (Gershwin, 2005a: 43, and references therein), as illustrated in Plate 3: linear horizontal (e.g., C. rastonii), linear vertical (e.g., Tamoya haplonema), crescentic horizontal (e.g., Alatina spp.), epaulette (e.g., C. branchi, C. marsupialis, C. mora, C. xaymacana), and lacking (Carukia spp., Malo spp., Morbakka, Gerongia). Carybdea branchi also differs from Tamoya in numerous other structural characters, for example, the latter has frownshaped rhopalial niche ostia, whereas in the former they are heart-shaped.

\section{Acknowledgments}

We are grateful to Michelle van der Merwe and Liz Hoensen of the South African Museum for their generosity of time and enthusiasm, and for helping us to access the collection; we are similarly grateful to the South Australian Museum for access to specimens and study facilities. We also thank George Branch, Elaine Robson, and the Two Oceans Aquarium for information about this species. This manuscript was improved by comments from Drs. Andre Morandini and Dale Calder, and an anonymous reviewer; we are grateful for their insights. We are indebted to Australian Biological Resources Study (Grants 20045 and 20763) for generous travel and writing support to the senior author. 


\section{References}

Bigelow, H.B. (1938) Plankton of the Bermuda Oceanographic Expeditions. VIII. Medusae taken during the years 1929 and 1930. Zoologica, N.Y., 23 (part 2), 99-189.

Branch, G.M., Griffiths, C.L., Branch, M.L. \& Beckley, L.E. (1994) Two Oceans: A guide to the Marine Life of Southern Africa. David Philip, Cape Town, 360 pp.

Calder, D.R. (1974) Nematocysts of the coronate scyphomedusa, Linuche unguiculata, with a brief reexamination of scyphozoan nematocyst classification. Chesapeake Science, 15, 170-173.

Gegenbaur, C. (1856) Versuch eines Systemes der Medusen, mit Beschreibung neuer oder wenig gekannter Formen; zugleich ein Beitrag zur Kenntniss der Fauna des Mittelmeeres. Zeitschrift fur Wissenschaftliche Zoologie, 8, 202-273, plates vii-x.

Gershwin, L. (2005a) Taxonomy and phylogeny of Australian Cubozoa. James Cook University, Townsville, Australia. 221 pp., 49 plates.

Gershwin, L. (2005b) Carybdea alata auct. and Manokia stiasnyi, reclassification to a new family with description of a new genus and two new species. Memoirs of the Queensland Museum, 51, 501-523.

Gershwin, L. (2006) Nematocysts of the Cubozoa. Zootaxa, 1232, 1-57.

Haeckel, E. (1880) System der Acraspeden. Zweite Halfte des System der Medusen. G. Fischer, Jena, pp. 361-672, 20 plates.

Kramp, P.L. (1955) The medusae of the tropical west coast of Africa. Atlantide Report, 3, 239-324.

Kramp, P.L. (1959) Medusae mainly from the West coast of Africa. Institut Royal des Sciences Naturelles de Belgique, 3, 1-33.

Kramp, P.L. (1961) Synopsis of the medusae of the world. Journal of the Marine Biological Association of the United Kingdom, 40, 1-469.

Linnaeus, C. (1758) Systema naturae per regna tria naturae, secundum classes, ordines, genera, species cum characteribus, differentïs, synonymis, locis. Editio decima, reformata. Laurentii Salvii, Holmiae, $824 \mathrm{pp}$.

Mariscal, R.N. (1971) Effect of a disulfide reducing agent on the nematocyst capsules from some coelenterates, with an illustrated key to nematocyst classification. In: Lenhoff, H.M., Muscatine, L. \& Davis, L.V. (Eds.) Experimental Coelenterate Biology. University of Hawaii Press, Honolulu, pp. 157-168.

Mayer, A.G. (1910) Medusae of the World. Vol. 3, The Scyphomedusae. Carnegie Institution, Washington, D.C., pp. 499-735.

Muller, F. (1859) Zwei neue Quallen von Santa Catharina. Abhandlungen der Naturforschenden Gesellschaft zu Halle, Bd. 5, 1-12, pls. I-III.

Pages, F., Gili, J.M. \& Bouillon, J. (1992) Medusae (Hydrozoa, Scyphozoa, Cubozoa) of the Benguela Current (southeastern Atlantic). Scientia Marina, 56, 1-64.

Peron, F. \& Lesueur, C.A. (1810) Tableau des caracteres generiques et specifiques de toutes les especes de meduses connues jusqu'a ce jour. Annales du Museum dhistoire naturelle, Paris, 14, 325-366.

Ranson, G. (1945) Les scyphomeduses de la collection du Museum National d'Histoire Naturelle Paris. II. Catalogue raisonne; origine des recoltes. Bulletin du Museum National d'Histoire Naturelle, Paris, Series 2, Tome 17, 312-320. 
Ranson, G. (1949) Resultats Scientifiques des Croisieres du Navire-Ecole Belge "Mercator", Vol. 4, Extrait II. Meduses.

Memoires Institute Royal des Sciences Naturelles de Belgique, Series 2, 33, 121-158.

Reynaud, M. (1830) Carybdea alata n. sp. In: Lesson, R.P. (Ed.) Centurie Zoologique. Levrault, Paris, p. 95, pl. 33.

Stiasny, G. (1934) Scyphomedusae. Discovery Reports, 8, 329-396, plates 14, 15.

Stiasny, G. (1939) Scyphomedusen von der Congomundung. Revue de Zoologie et de Botanique Africaines, 33, 42-43.

Uchida, T. (1970) Revision of Japanese Cubomedusae. Publications of the Seto Marine Biological Laboratory, 17, 289-297.

Werner, B. (1973) New investigations on systematics and evolution of the class Scyphozoa and the phylum Cnidaria. Publications of the Seto Marine Biological Laboratory, 20 (Proceedings of the Second International Symposium on Cnidaria), 35-61.

Werner, B. (1984) Klasse Cubozoa. In: Gruner, H.E. (Ed.) Lehrbuch der Speziellen Zoologie. Gustav Fischer Verlag, Stuttgart, pp. 106-133.

Williamson, J.A., Fenner, P.J., Burnett, J.W. \& Rifkin, J. (1996) Venomous and Poisonous Marine Animals: A Medical and Biological Handbook. Sydney, Australia, NSW University Press, 504 pp. 